UDC 614.71

DOI: $10.21668 /$ health.risk/2018.2.09.eng

\title{
HOW TO REDUCE RISKS RELATED TO BIOLOGICAL FACTOR IMPACTS ON RAILWAY TRANSPORT WORKERS
}

\author{
M.F. Vil'k', O.S. Sachkova', I.G. Khamanov², S.Yu. Alekhin², \\ V.A. Aksel'rod', A.M. Koroleva ${ }^{2}$ \\ ${ }^{1}$ All-Russian Research Institute of Railway Hygiene, 1, Bldg. 1 Pakgauznoe Shosse, Moscow, 125438, \\ Russian Federation \\ ${ }^{2}$ Russian University of Transport (MIIT), 9, Bldg. 9 Obrazcova Str., Moscow, 127994, Russian Federation
}

The paper focuses on impacts exerted by occupational biological factors on railway transport workers. The authors showed that these impacts resulted in significant social and economic losses and caused about $40 \%$ of overall morbidity with temporary disability. It was also proved that a basic parameter of biological safety in a working zone was full conformity of air in it to requirements set forth by the existing standards. The authors justify the necessity to improve working conditions for railway transport workers allowing for adverse biological impacts. The following devices were created and patented: 1) a device to disinfect air indoors, with its basic working principle being combined influences exerted on air being disinfected, namely ionization and high frequency ultrasound exposure with frequency being within 1 to $3 \mathrm{MHz}$ range; 2) a shock absorber for an elevator shaft made up of materials unsusceptible to pathogenic microorganisms. The paper contains two variants of designed specifications for an air-disinfecting device: for small volume rooms (up to $300 \mathrm{~m}^{3}$ ) and for greater ones, their volume being up to $5.000 \mathrm{~m}^{3}$. If shock absorbers which we suggest are applied instead of bio-destructive ones, it will allow to eliminate a major source of pathogenic microorganisms and mold fungi in administrative, communal, and passenger premises. Besides, the authors showed that the developed shock absorber was more efficient in emergency cases due to being made of materials with different density, two-layer structure, and vertical layout of its elements. A predicted social and economic effect which we can expect due to implementation of the proposed working conditions improvements was assessed in conformity with the guidelines approved by the Federal Law No. 255-FL issued on December 29, 2006.

Key words: working conditions, biological factor, working conditions assessment, labor protection, risk, occupational hygiene, railway transport, morbidity.

Social and economic development in Russia is linked directly to the demographic situation in the country and, above all, to the quality of the state's labor resources, determined by the number, health status and social well-being of the employ- able population. Taking into account special working factors of the railway industry staff, one can say that a significant part of them are in the risk zone of exposure to pathogenic microorganisms (working environment biological factor). Representatives

(C) Vil'k M.F., Sachkova O.S., Khamanov I.G., Alekhin S.Yu., Aksel'rod V.A., Koroleva A.M., 2018

Mikhail F. Vil'k - Doctor of Medical Sciences, Professor, Director (e-mail: info@vniijg.ru; tel.: +7 (499) 153-27-37).

Oksana S. Sachkova - Doctor of Technical Sciences, Associate Professor, Leading Researcher at Laboratory for Communal Hygiene and Epidemiology (e-mail: vniijg@yandex.ru; tel.: +7 (926) 899-73-06).

Ivan G. Khamanov - a post-graduate student at Technosphere Safety Department of the Russian Transport University (e-mail: ivanjimm@rambler.ru; tel.: +7 (913) 768-69-84).

Sergei Yu. Alekhin - a post-graduate student at Technosphere Safety Department (e-mail: vikieco@yandex.ru; tel.: +7 (917) 592-01-56).

Vladimir A. Aksel'rod - a post-graduate student at Technosphere Safety Department (e-mail: vikieco@yandex.ru; tel.: +7 (917) 592-01-56).

Anna M. Koroleva - Senior Lecturer at Department for Technosphere Safety Management (e-mail: annakoroleva@list.ru; tel.: +7 (499) 176-45-13). 
of railway workers' professions are in contact with media that do not meet standards not only in terms of microbiological parameters, but also of parasitic indicators [1, 2]. The exposure to biological factor in the railway sector, by more than $40 \%$, determines negative dynamics of morbidity with temporal disability (MTD).

The formal professional approach adopted for special assessment of working conditions (SAWC) does not allow identify the biological factor in most of the workplaces at railway transport enterprises, since it is not included in the Federal Law "On Special Assessment of Working Conditions" $^{1}$ and the Procedure for SAWC [36]. All of the above has a negative impact on employees' safety, and reduces functional intensity of the industry's labor protection services for ensuring personnel biological safety. So, for example, the facts of workers diseases and deaths due to infections carriers and products of their vital ac- tivity are completely excluded from the legal framework. For a number of jobs, the effect of pathogenic microorganisms [7-9] has not been taken into account.

One of the most informative criteria in assessing the cause-effect relationships of workers' health loss and working conditions is the incidence of temporal disability (MTD). Based on Russian Federal State Statistics Service (Rosstat) data, it's been proved that the cause of MTD cases among the Russian Federation working population, in the period between 1990 and 2016, in 38 to $41 \%$ were the consequences of exposure to pathogenic microorganisms by airborne transmission $[10,11]$. At the railway industry enterprises, according to the Central Directorate of Healthcare, a branch of OJSC «Russian Railways», this percentage is even higher, which is due to the industry features of working conditions.

Table 1 shows MTD analysis figures for West Siberian Railway.

Table 1

Share of the diseases per categories and ICDs, and their rank in the structure of temporal disability among the West Siberian Railway employees

\begin{tabular}{|c|c|c|c|c|c|c|c|c|c|}
\hline \multirow{2}{*}{ No } & \multirow{2}{*}{$\begin{array}{c}\text { Disease category and individual } \\
\text { nosological forms }\end{array}$} & \multicolumn{2}{|c|}{1995} & \multicolumn{2}{|c|}{2005} & \multicolumn{2}{|c|}{2010} & \multicolumn{2}{|c|}{2017} \\
\hline & & $\%$ & Rank & $\%$ & Rank & $\%$ & Rank & $\%$ & Rank \\
\hline 1 & $\begin{array}{l}\text { A.R.V.I (airborne droplet } \\
\text { transmission of infection) }\end{array}$ & 43,71 & $\mathbf{I}$ & 43,34 & $\mathbf{I}$ & 42,71 & I & 40,62 & $\mathbf{I}$ \\
\hline 2 & $\begin{array}{l}\text { Diseases of musculoskeletal } \\
\text { system and connective tissue }\end{array}$ & 14,79 & II & 18,02 & II & 17,28 & II & 17,12 & II \\
\hline 3 & Diseases of respiratory system & 9,60 & III & 8,62 & III & 8,77 & III & 8,69 & III \\
\hline 4 & $\begin{array}{l}\text { Injuries and poisoning in every- } \\
\text { day life }\end{array}$ & 5,71 & IV & 7,57 & IV & 8,64 & IV & 8,74 & IV \\
\hline 5 & $\begin{array}{l}\text { Cardiovascular diseases } \\
\text { including: }\end{array}$ & 5,71 & IV & 5,09 & VI & 3,40 & VI & 3,45 & VI \\
\hline 6 & Diseases of digestive system & 5,32 & $\mathrm{~V}$ & 5,74 & $\mathrm{~V}$ & 6,15 & $\mathrm{~V}$ & 6,11 & $\mathrm{~V}$ \\
\hline 7 & $\begin{array}{l}\text { Infections of skin and subcuta- } \\
\text { neous tissue }\end{array}$ & 3,11 & VI & 2,87 & VII & 2,75 & VII & 2,65 & VII \\
\hline 8 & Other & 12,05 & - & 8,75 & - & 10,3 & - & 12,62 & - \\
\hline 9 & $\begin{array}{l}\text { Total for all diseases (in } \\
\text { percent) }\end{array}$ & 100,0 & - & 100,0 & - & 100,0 & - & 100,0 & - \\
\hline
\end{tabular}

\footnotetext{
${ }^{1} \mathrm{O}$ spetsial'noi otsenke uslovii truda: Federal'nyi zakon № 426-FZ ot 28.12.2013 g. [On a special assessment of working conditions: $\quad$ Federal Law No. 426-FZ of December 28, 2013]. GARANT. Available at: http://base.garant.ru/70552676/\#friends (18.02.2018) (in Russian).
} 
Currently, using materials that are resistant to biodegradation, especially the ones used for passenger cars finishing, is topical. Materials exposed to microorganisms are the medium for their growth, which in turn leads to an increase in the level of air bacterial contamination [12, 13].

It turned out that microorganisms destroy a shock absorber made of foam rubber, used as a backup protection system. Such shock absorber is located in the bottom of an elevator shaft and is necessary to mitigate the fall of an elevator car in case of emergency. Biodegradation of foam rubber is accompanied by an increased concentration of pathogenic microorganisms in the air due to regular movements of an elevator car in a shaft. The intensity of biodegradation increases with dampness, insufficient ventilation in an elevator shaft.

JSCo «Russian Railways» uses passenger and freight-passenger elevators in administrative and passenger buildings. «Russian Railways» is actively involved in equipping the passenger infrastructure facilities with elevators and lifts for lowmobility population groups, which is dictated by the state program "Accessibility" for 2011-2020.

The purpose of this paper is to develop ways to reduce risk and exposure level to the negative biological factor in production environment on the railway industry employees with the estimation of predicted benefits from the proposed methods to be introduced.

Material and methods. Viral dis- eases of respiratory organs form a consistently high level of MTD at the enterprises of JSCo «Russian Railways». Viral diseases are frequently observed among the roadlines service workers, in particular. In order to ensure safe working conditions, special attention should be paid to microbial indices of the air in the working zones, rest areas and common areas on site. It is necessary to introduce modern decontamination and operational air quality control systems, which are permitted for use at railway transport facilities. At present, there are devices introduced that implement ultraviolet air disinfection technology. For some working zones, one can use equipment that functions with the combined effect of ionization and high-frequency ultrasound in the frequency range from 1-3 $\mathrm{MHz}^{2}$ [14]. Ultrasonic effect makes it possible to obtain an excessively fine dispersed aerosol in a liquid-gas system, and also to enhance disinfection capacity of the device [15, 16]. Within the specified frequency range, airborne ultrasound does not have negative effect on humans [17]. The patented device provides: high efficiency of air disinfection for individual working areas; absence of negative impact on the worker's organism when used; low power consumption, versatility from the point of installation and connection to mains.

Table 2 presents the designed technical specifications of the developed device for working areas disinfection.

Results and discussion. A two-layer shock absorber ${ }^{3}$, made of flexible elastomeric foam and neoprene has been

\footnotetext{
${ }^{2}$ Shchetinin A.N., Khamanov I.G., Latyshov D.A., Evstegneeva A.A. Ustroistvo dlya obezzarazhivaniya atmosfernogo vozdukha v pomeshchenii: patent 150551, Rossiiskaya Federatsiya, MPK A61L 9/16 (2006.01) [Device for disinfection of atmospheric air in the room: patent 150551, Russian Federation MPK A61L 9/16 (2006.01)]. No. 2014115041/15; zayavl. 15.04.2014; opubl. 20.02.2015. Byul. № 5. Novosibirsk, SGUPS.(RU) (in Russian).

${ }^{3}$ Shchetinin A.N., Khamanov I.G., Tokareva N.E. Amortizator dlya lifta: patent 169344, Rossiiskaya Federatsiya, MPK V66V 5/28 (2006.01). Zayavitel' i patentoobladatel' Sibirskii gosudarstvennyi universitet putei soobshcheniya [Elevator shock absorber: Patent 169344 Russian Federation, IPC B66B 5/28 (2006.01). Applicant and Patent holder Siberian State Transport University] appl. 01/04/2016; publ. 15.03.2017, Bul. № 8, 1 p. (in Russian).
} 
Specifications of the device for working areas disinfection

\begin{tabular}{|c|l|c|c|}
\hline \multirow{2}{*}{ No } & \multicolumn{1}{|c|}{ Specifications } & \multicolumn{2}{|c|}{ Device developed } \\
\cline { 3 - 4 } & & For working zones & $\begin{array}{c}\text { For supply (supply and exhaust) venti- } \\
\text { lation systems of working }\end{array}$ \\
\hline 1 & Capacity, $\mathrm{m}^{3} /$ hour & 310 & 5106 \\
\hline 2 & Power consumption, Wt & 45 & 250 \\
\hline 3 & $\begin{array}{l}\text { Frequency range of the emitted } \\
\text { ultrasound, } \mathrm{MHz}\end{array}$ & $1-3$ & $1-3$ \\
\hline 4 & Room volume, $\mathrm{m}^{3}$ & Below 300 & below 5000 \\
\hline 5 & Feeding electrical power, $\mathrm{V} / \mathrm{Hz}$ & $220 / 50$ & $220 / 50$ \\
\hline 6 & $\begin{array}{l}\text { Working cycle duration } \\
\text { (work/technical break), } \mathrm{h}\end{array}$ & $6 / 0,5$ & $6 / 0,5$ \\
\hline 7 & Volume of water to be poured, & 10 & Дo 100 \\
\hline 8 & $\begin{array}{l}\text { Dimensions, mm } \\
\text { (n) }\end{array}$ & $360 \times 295 \times 290$ & $\begin{array}{c}\text { ionizer } 711 \times 660 \times 457, \\
\text { emitter } 390 \times 353 \times 353, \\
\text { capacity } 500 \times 505 \times 505\end{array}$ \\
\hline 9 & $\begin{array}{l}\text { Weight, including water to be filled } \\
\text { in, kg }\end{array}$ & 15 & below 137 \\
\hline 10 & Noise level, dBA & 41 max & 50 max \\
\hline
\end{tabular}

The utility model sketch is shown in

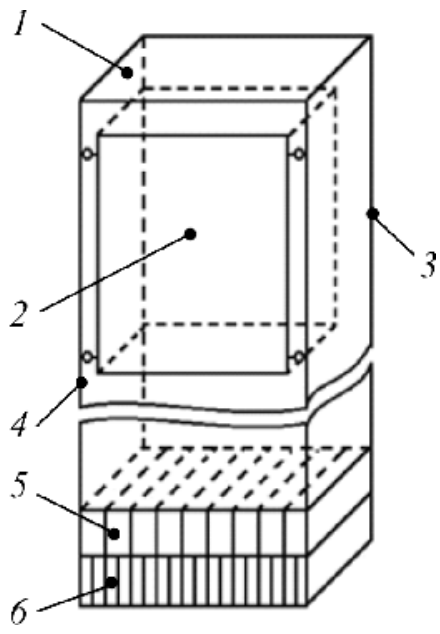

Figure. 1. An elevator shaft with a proposed two-layer shock absorber: 1 - elevator shaft; 2

- elevator car; 3, 4- sliding guide-ways;

5, 6 - double-layer absorber

developed. These materials, unlike the ones used, are immune to the effects of microorganisms, hence if applied it will reduce concentration of pathogenic microorganisms and mold fungi in the air in public places of administrative, communal, and passenger premises.
Figure 1. Characteristics of the proposed and applied materials for shock absorber are given in Table 3.

Such absorber is made as a threedimensional body consisting of different density layers. Layers are being placed with the possibility to be shifted relative to each other; each layer of volumetric body is made in the form of prismatic elements, installed vertically. Such arrangement of elements enables more efficient shocks absorption and bounce minimization. The proposed absorption layers are placed in the pit of an elevator shaft. The obtained values of thickness and cushioning layers area for the proposed materials do not exceed pits sizes for typical elevators shafts, so no technical modifications will be required at installation.

The proposed shock absorber in use for the elevator contributes to solving two problems: 
Specifications for materials used and proposed

\begin{tabular}{|c|l|c|c|c|}
\hline \multirow{2}{*}{ No } & \multicolumn{1}{|c|}{ Specification } & \multicolumn{3}{c|}{ Materials } \\
\cline { 3 - 5 } & Polyurethane foam & $\begin{array}{c}\text { Flexible elastomeric } \\
\text { foam }\end{array}$ & Neoprene \\
\hline 1 & Apparent density, $\mathrm{kg} / \mathrm{m}^{3}$ & $25-30$ & $40-65$ & $66-200$ \\
\hline 2 & $\begin{array}{l}\text { Modulator of direct elasticity, } \\
\mathrm{kPa}\end{array}$ & $3,5-4,5$ & 8 & $10-15,5$ \\
\hline 3 & Elasticity & high & high & high \\
\hline 4 & Operating temperature range & Oт -15 до $100{ }^{\circ} \mathrm{C}$ & От -50 до $105^{\circ} \mathrm{C}$ & От -55 до $90^{\circ} \mathrm{C}$ \\
\hline 5 & Moisture resistance & $\begin{array}{c}\text { destroyed in a hu- } \\
\text { mid environment }\end{array}$ & waterproof & waterproof \\
\hline 6 & Combustibility & combustible & low-combustible & low-combustible \\
\hline 7 & Wear resistance & nondurable & durable & durable \\
\hline 8 & $\begin{array}{l}\text { Susceptibility to microorgan- } \\
\text { isms }\end{array}$ & $\begin{array}{c}\text { destroyed when } \\
\text { exposed to micro- } \\
\text { organisms }\end{array}$ & resistant & resistant \\
\hline
\end{tabular}

Table 4

Initial data for calculating economic effect of the proposed ways to improve working conditions

\begin{tabular}{|c|c|c|c|c|}
\hline Index & $\begin{array}{c}\text { Number of } \\
\text { employees }\end{array}$ & $\begin{array}{c}\text { Normative } \\
\text { period for } \\
\text { calculating } \\
\text { average earnings }\end{array}$ & $\begin{array}{c}\text { Average monthly } \\
\text { salary of an employee } \\
\text { at JSCo «Russian } \\
\text { Railways» and its } \\
\text { branches }\end{array}$ & $\begin{array}{c}\text { Number of temporal disability } \\
\text { cases at JSCo «Russian } \\
\text { Railways» due to biological } \\
\text { factor, for a calendar year }\end{array}$ \\
\hline Value & 756000 people $^{1}$ & $\begin{array}{c}730 \text { calendar } \\
\text { days }^{2}\end{array}$ & 25 th. Rub. & 178315 cases $^{3}$ \\
\hline
\end{tabular}

Notes:

${ }^{1}$ As of 01.01.2017, based on analysis data of labor protection status and conditions at JSCo «Russian Railways» for 2016. (Ref.-5305 dated March 24, 2017).

${ }^{2}$ According to Part 1, Article 14, No. 255-FZ of 29.12.2006 "On Compulsory Social Insurance for Tempory Disability and Cases related to Maternity"4.

${ }^{3}$ According to the Central Directorate of Healthcare, a branch of JSCo «Russian Railways».

- reducing the risk of biological factor' negative impact on workers in administrative and passenger buildings by eliminating one of the sources;

- increasing the effectiveness of backup protection system of lifting and transport mechanism to save people's lives in case of elevator car falling into a shaft.

The forecasted economic component is estimated according to the procedure approved by the Federal Law "On Compulsory Social Insurance for Tempory Disability and Cases related to Maternity" dated 29.12.2006 No. 255-F $\mathrm{F}^{4}$. Economic efficiency is achieved by reducing payments for tempory disability due to illness with acute respiratory viral infections (A.R.V.I). The initial data for

\footnotetext{
${ }^{4}$ Ob obyazatel'nom sotsial'nom strakhovanii na sluchai vremennoi netrudosposobnosti i v svyazi s materinstvom: Federal'nyi zakon № 255-FZ ot 29.12.2006 g. [On Compulsory Social Insurance for Tempory Disability and Cases related to Maternity: Federal Law ddt. 29.12.2006, No. 255-FZ]. Konsul'tantPlyus. Available at: http://www.consultant.ru/document/cons_doc_LAW_64871/(18.02.2018) (in Russian).
} 
calculations are given in Table 4.

The daily average earnings $E_{\text {d.a. }}$ is determined according to Part 3, Article 14, No. 255-FZ of 29.12.2006 ${ }^{4}$ :

$$
S_{\text {d.a. }}=\frac{\text { S earnings }}{730} \text {. }
$$

where $S$ earnings is the sum of a worker's earnings for a settlement period (during recent 730 calendar days).

The daily allowance for temporal disability $\mathrm{A}_{\text {t.d. }}$ is determined according to Part 4, Article 14, No. 255-FZ of 29.12.2006 ${ }^{4}$ :

$$
\mathrm{DA}_{\mathrm{t} . \mathrm{d} .}=\mathrm{S}_{\text {earnings }} \mathrm{P}_{\mathrm{a} . \mathrm{e}}
$$

where $P_{\text {a.e. }}$ is the percentage of average earnings, depending on a worker's employment period.

The percentage of average earnings is calculated depending on a worker's employment period and makes, in accordance with Part 1, Article 7 No. 255FZ of December 29, $2006^{4}$ :

$-100 \%$ of the average earnings with an insurance period of 8 years or more;

$-80 \%$ of the average earnings with an insurance period from 5 to 8 years;

$-60 \%$ of the average earnings with an insurance period of up to 5 years.

To calculate the daily allowance, the value of $80 \%$ of the average earnings is taken.

The amount for temporal disability allowance $A_{\text {t.d. }}$ is determined in accordance with the Part 5, Article 14 No. 255-FZ of 29.12.2006 :

$$
\mathrm{A}_{\mathrm{t} . \mathrm{d} .}=\mathrm{DA}_{\mathrm{t} . \mathrm{d} .} \mathrm{D}_{\mathrm{t.d.}} \text {, }
$$

where $D_{\text {t.d. }}$ - the days of temporal disability according to a sick leave. For calculations, 7 days are taken as temporal disability period due to biological factor.

The calculation results are given in Table 5.

In accordance with the current legislation, payment of temporal disability allowances is made from the funds of the Russian Federation Social Insurance Fund (SIF) and at the expense of an employer. The first three days of a sick leave, in case of correct filling and registration, are paid by an employer, the rest days - from SIF. Taking into account the accepted condition ( 7 days are taken as temporal disability period due to biological factor), we will describe the distribution of a financial burden of paying allowances due to temporal disability between SIF and JSCo «Russian Railways» in Figure 2.

As a result of a set of activities to reduce exposure to biological factor on the railway industry workers, MTD level due to biological factor will decrease by $15-$ $35 \%$.

Table 5

The results of calculating the average amount for temporal disability allowance due to biological factor, at JSCo «Russian Railways»

\begin{tabular}{|c|c|c|c|c|}
\hline Index & $\begin{array}{c}\text { Average } \\
\text { daily } \\
\text { earnings }\end{array}$ & $\begin{array}{c}\text { Amount of } \\
\text { daily } \\
\text { allowance }\end{array}$ & $\begin{array}{c}\text { The amount of } \\
\text { temporal disability } \\
\text { allowance for a } \\
\text { single case }\end{array}$ & $\begin{array}{c}\text { Total amount of temporal dis- } \\
\text { ability allowance due to bio- } \\
\text { logical factor, at JSCo «Rus- } \\
\text { sian Railways» }\end{array}$ \\
\hline Value & $\begin{array}{c}0,82192 \\
\text { kRub. }\end{array}$ & 0,65754 kRub. & 4,60278 kRub. & $820744,7157 \mathrm{kRub.}$ \\
\hline
\end{tabular}




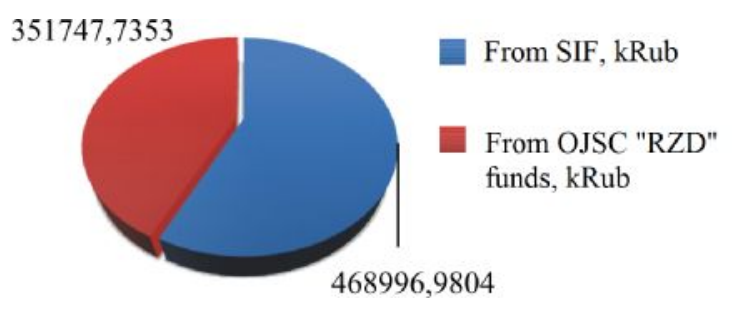

Fig. 2. Distribution of temporal disability allowances' payments to JSCo «Russian Railways» employees due to biological factor

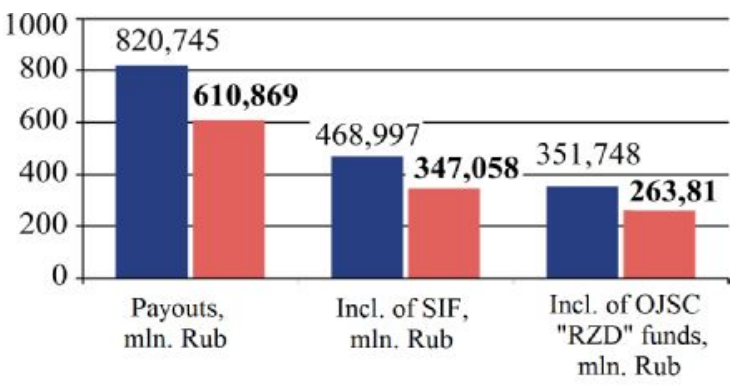

Befor implementation

After implementation

Fig.3. Forecasted economic effect of a set of activities to improve working conditions of JSCo «Russian Railways» employees

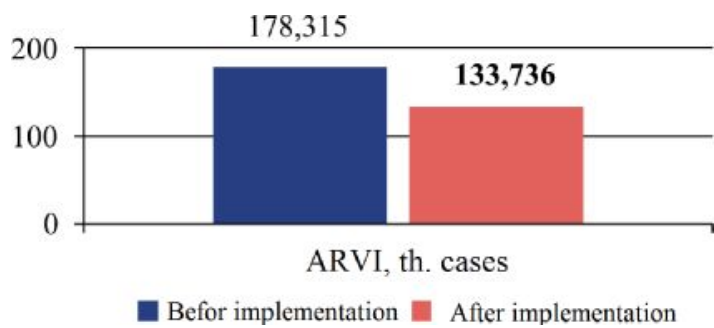

Fig. 4. Forecasted social effect of a set of activities to reduce impact of biological factor for JSCo «Russian Railways»

Figures 3 and 4 show the results of assessing social and economic efficiency of activities to reduce exposure to biological factors of «Russian Railways» employees.

Social performance of the introduced set of measures to reduce impact of biological factor for employees of JSCo
«Russian Railways»:

- in reducing MTD level among workers in the railway industry;

- in improving working conditions (bringing the working zone air in compliance with the requirements set out with the Order No. 33n of the Ministry of Labor ddt. 24.01.2014 and SP 2.5.1198-03 ${ }^{5}$ ) and, as a consequence, in reducing the level of occupational risk;

- in increasing labor performance.

It's been proved that exposure to biological factor of the railway industry workers leads to significant social and economic losses. We confirmed that the main indicator of biological safety is the compliance of air environment with the requirements of effective standards. We justified the necessity and development of new ways to improve working conditions, taking into account negative biological effects. We did the prognostic assessment of the socioeconomic effect from the proposed methods for improving working conditions.

Conclusions. An integrated application of the proposed methods to improve working conditions at the railway industry enterprises will significantly reduce risk of the biological factor negative effect on workers. Implementation thereof will allow for:

- reducing MTD level;

- reducing payments for temporal disability;

- improvements in the working conditions (bringing the working zone air into compliance with the requirements set out in the Order No. 33n of the Ministry of La-

\footnotetext{
${ }^{5} \mathrm{Ob}$ utverzhdenii Metodiki provedeniya spetsial'noi otsenki uslovii truda, Klassifikatora vrednykh i (ili) opasnykh proizvodstvennykh faktorov, formy otcheta o provedenii spetsial'noi otsenki uslovii truda i instruktsii po ee zapolneniyu (s izmeneniyami na 14 noyabrya 2016 goda): Prikaz Ministerstva truda i sotsial'noi zashchity Rossiiskoi Federatsii [On approval of the Methodology for conducting special assessment of working conditions, the Classifier of harmful and (or) hazardous production factors, report forms on a special assessment of working conditions and instructions for filling it (as amended on November 14, 2016): Order of Ministry of Labor and Social Protection of Russian Federation]. KODEKS: Elektronnyi fond pravovoi $i$ normativnotekhnicheskoi dokumentatsii. Available at: http://docs.cntd.ru/document/499072756 (18.02.2018) (in Russian).
} 
bor ddt. 24.01.2014 and SP 2.5.1198-03) and, as a consequence, reducing the level of occupational risk;

- increase in labor performance by reducing MTD level and improving working conditions.
Funding. Our research was not granted any sponsors' support.

A conflict of interests. The authors state there is no conflict of interests.

\section{References}

1. Kas'kov Yu.N., Podkorytov Yu.I., Kas'kova O.Yu. Biologicheskaya bezopasnost' na ob"ektakh zheleznodorozhnogo transporta Rossiiskoi Federatsii [Biosafety at the railway transport objects of the Russian Federation]. Gigiena i sanitariya, 2010, no. 5, pp. $28-31$ (in Russian).

2. Kas'kov Yu.N., Podkorytov Yu.I. Sovremennoe sostoyanie i reshenie voprosov sanepidblagopoluchiya na ob"ektakh zheleznodorozhnogo transporta Rossii [Current status and aspects of solving issues of sanitary and epidemiological well-being at the facilities of railway transport in Russia]. Gigiena i sanitariya, 2012, no. 5, pp. 37-40 (in Russian).

3. Vadulina N.V., Fedosov A.V., Rakhmatullina S.S. Otsenka biologicheskogo faktora na rabochikh mestakh [Assessment of biological factors of workplaces]. Neftegazovoe delo, 2014, no. 1, pp. 164-167 (in Russian).

4. Sklemenov, G.Zh., Yuzhaninova L.V. Otsenka biologicheskogo faktora pri provedenii spetsial'noi otsenki uslovii truda meditsinskikh rabotnikov [Biological factors in the study of medical staff conditions of work]. Bezopasnost' i okhrana truda, 2016, no. 4, pp. 33-35 (in Russian).

5. Bulgakova E.V., Okromelidze N.R. Osobennosti otsenki biologicheskogo faktora u meditsinskii rabotnikov [Peculiarities of biological factors assessment in case of medical]. Neft' $i \mathrm{gaz}$ Zapadnoi Sibiri: materialy Mezhdunarodnoi nauchno-tekhnicheskoi konferentsii, posvyashchennoi 90-letiyu so dnya rozhdeniya Kosukhina Anatoliya Nikolaevicha. Tyumen', Izd-vo TIU Publ., 2015, pp. 237-239 (in Russian).

6. Min'ko V.M., Evdokimova N.A. O problemakh ob"ektivnoi otsenki biologicheskogo faktora pri issledovaniyakh uslovii truda [On the Problems of an Objective Assessment of the Biological Factor in Studies of Working Conditions]. Bezopasnost' zhiznedeyatel'nosti, 2016, no. 10, pp. 3-8 (in Russian).

7. Belova T.I., Burak V.E., Dontsov S.A. Sravnitel'naya otsenka ARM-SOUT i biologicheskii faktor [WPC-SAWC (working places e certification - specific assessment of working conditions) comparative assessment and the biological factor]. Sotsial'no-ekonomicheskie $i$ pravovye osnovy razvitiya ekonomiki. Ufa, OOO «MEGAS SAINS» Publ., 2015, pp. 74-86 (in Russian).

8. Kadochnikov D.S., Minaeva P.V. Voprosy sovershenstvovaniya zakonodatel'stva, reguliruyushchego otsenku tyazhesti vreda zdorov'yu ot vozdeistviya biologicheskogo povrezhdayushchego [Improvement of legislation governing the assessment of severity of damage to health by impact of biological damaging factor]. Vestnik sudebnoi meditsiny, 2016, no. 4, pp. 15-19 (in Russian).

9. Fedosov A.V., Askarova A.A. Modelirovanie biologicheskogo faktora pri spetsial'noi otsenke uslovii truda [Modeling of a Biological Factor at Special Assessment of Working Conditions]. Bezopasnost' zhiznedeyatel'nosti, 2016, no. 1, pp. 14-17 (in Russian).

10. Dar'ina M.G., Movchan K.N., Zakhvatova A.S., Svetlichnaya Yu.S., Tekhova I.G., Mamicheva O.Yu., Rusakevich K.I. Vliyanie biologicheskikh faktorov proizvodstvennoi sredy na zabolevaemost' meditsinskikh rabotnikov statsionarov Sankt-Peterburga [Impacts exerted by 
occupational biological factors on morbidity among medical staff at Saint-Petersburg in-patient hospitals]. Zdorov'e - osnova chelovecheskogo potentsiala: problemy i puti ikh resheniya, 2017, vol. 10, no. 1, pp. 423-424 (in Russian).

11. Figurovskii A.P., Mozzhukhina N.A., Topanov I.O., Khomulo D.P. Gigienicheskaya otsenka biologicheskogo faktora na musoropererabatyvayushchem predpriyatii [Hygienic assessment of a biological factor at a garbage-processing enterprise]. Gigiena i sanitariya, 2010, no. 5, pp. 31-32 (in Russian).

12. Bukharev G.M., Laptev A.B., Yakovenko T.V., Bobyreva T.V. Rol' otsenki biologicheskogo faktora $\mathrm{v}$ obespechenii bezopasnoi ekspluatatsii slozhnykh tekhnicheskikh sistem $\mathrm{v}$ techenie zhiznennogo tsikla [A role which biological factor assessment plays in providing safe operations of complicated technical systems during their lifecycle]. Klimat-2017. Problemy otsenki klimaticheskoi stoikosti materialov i slozhnykh tekhnicheskikh sistem: sbornik dokladov II Vserossiiskoi nauchno-tekhnicheskoi konferentsii. Gelendzhik, 2017, pp. 21-30 (in Russian).

13. Kopytenkova O.I., Shilova E.A., Sazonova A.M., Slyusareva O.V. Kompleksnyi podkhod $\mathrm{k}$ probleme otsenki biologicheskogo faktora [Comprehensive approach to the problem of biological factor]. Gigiena i sanitariya, 2017, no. 7, pp. 610-614 (in Russian).

14. KhamanovI.G., Shchetinin A.N., Evstegneeva A.A. Optimizatsiya metodologicheskikh podkhodov k ponyatiyu «biologicheskii faktor» primenitel'no $\mathrm{k}$ zheleznodorozhnomu transportu [Optimization of methodological approaches to the concept of "biological factor" priminitelno rail transport]. Izvestiya Transsiba, 2015, no. 2 (22), pp. 122-130 (in Russian).

15. Khmelev V.N., Shalunov A.V., Shalunova A.V. Ul'trazvukovoe raspylenie zhidkostei [Ultrasound liquid atomization]. Biisk, Izdatel'stvo Altaiskogo gosudarstvennogo tekhnicheskogo universiteta Publ., 2010, 272 p. (in Russian).

16. Khmelev V.N., Leonov G.V., Barsukov R.V., Tsyganok S.N., Shalunov A.V. Ul'trazvukovye mnogofunktsional'nye i spetsializirovannye apparaty dlya intensifikatsii tekhnologicheskikh protsessov v promyshlennosti, sel'skom i domashnem khozyaistve: monografiya [Ultrasound multi-functional and specialized devices applied to intensify technological processes in industry, agriculture and households: a monograph]. Biisk, Izdatel'stvo Altaiskogo gosudarstvennogo tekhnicheskogo universiteta Publ., 2007, 400 p. (in Russian).

17. Reznikova S.V. Terapevticheskoe primenenie ul'trazvukovykh voln [Therapeutic application of ultrasound waves]. Blagoveshchensk, GOU VPO «AGMA» Publ., 2007, 25 p. (in Russian).

Vil'k M.F., Sachkova O.S., Khamanov I.G., Alekhin S.Yu., Aksel'rod V.A., Koroleva A.M. How to reduce risks related to biological factor impacts on railway transport workers. Health Risk Analysis, 2018, no. 2, pp. 78-86. DOI: 10.21668/health.risk/2018.2.09.eng

Received: 19.03.2018

Accepted: 17.06.2018

Published: 30.06 .2018 